\title{
ヘモグロビン濃度から推定される血液透析療法患者の 血中エリスロポエチン値
}

\author{
若杉 和 倫 外山圭助* 五十嵐かおる** 山根 伸 吾** \\ 延藤 卓生** 東 仲宣** 鈴 木 満** \\ 東京医科大学八王子医療センタ一免疫血液内科 東京医科大学內科* 東葛クリニック** \\ (平成 1 年 7 月 29 日受付, 同 2 年 6 月 21 日受理)
}

key words : erythropoietin, renal anemia, iron deficiency anemia

〈要旨〉

腎不全による血液透析（HD）療法中の患者の血清 erythropoietin (EPO) 值は一般に低いといわれているが, 負血 の一つの指標である血色素との関係で，つまり賓血に比較してどの程度低いのかという報告が少ない，そこで私ども は HD 患者の EPO 值を鉄欠乏性賓血（IDA）患者の EPO 值と比較し，血色素量との関係において検討した。 また EPO による HD 患者資血治療の際，血色素量よりみた EPO 投与量の推定をも合わせて検討した，关の結果，1。 $\mathrm{HD}$ 患者 100 名（うち 2 名は多囊胞腎にて除外）の EPO 濃度は $11.0 \pm 5.3 \mathrm{mU} / \mathrm{ml} 41$ 名の IDA 患者では $37.4 \pm$ $118.5 \mathrm{mU} / \mathrm{ml}, 73$ 名の健常人では $14.9 \pm 4.6 \mathrm{mU} / \mathrm{m} l$ であった．2．血色素量と EPO 濃度より得られる関係はIDA 患者では $r=-0.80, y=7,726 \mathrm{e}^{-0.63 x}$ であり, HD 患者では $r=-0.16, y=14.4 e^{-0.044 x}$ で表現され, これらから得ら れる両疾患群の解離は $\mathrm{Hb}$ 濃度が低下するほど広くなるという結果を得た。 3．よって，Hb 濃度よりみる HD 患者 の血中 EPO 濃度は IDA 患者の EPO 濃度に比較すると著明に低い，今後これらの結果は EPO による HD 患者の貧 血治療に役立ち得るものと考える。

\section{Serum erythropoietin titers in hemodialysis patients as estimated from hemoglobin levels}

Kazunori Wakasugi, M. D., Keisuke Toyama, M. D.*, Kaoru Igarashi**, Shingo Yamane**, Takuo Nobuto, M. D.**, Nakanobu Azuma, M. D.**, Mitsuru Suzuki, M. D.**

Department of Internal Medicine Immunohematology, Tokyo Medical College at Hachioji ; Department of Internal Medicine, Tokyo Medical College* ; Tokatsu Clinic**

Serum erythropoietin (EPO) titers in patients undergoing chronic regular hemodialysis (HD), with iron deficiency anemia (IDA) and in normal adult controls were determined using radioimmunoassay (RIA). The results are summarized as follows : 1 . The EPO titers of 100 patients with HD (two cases were excluded due to polycystic kidney) were $11.0 \pm 5.3 \mathrm{mU} / \mathrm{m}$ l of 41 patients with IDA were $37.4 \pm 118.5 \mathrm{mU} / \mathrm{m} l$ and 73 normal adult controls were $14.9 \pm 4.6 \mathrm{mU} / \mathrm{m}$ l. 2. Correlations obtained between EPO titers and hemoglobin $(\mathrm{Hb})$ volumes are as follows : IDA : $r=-0.80, y=7,726 e^{-0.63 x}, H D: r=-0.16, y=14.4 e^{-0.044 x}$. The differences between the two disease groups based on these results suggest that the lower the $\mathrm{Hb}$ levels, the wider the dissociation tendency.

3. Accordingly, serum EPO levels were found to be markedly lower in HD than in IDA.

はじめに

一般に貧血の発症する要因は，1.赤血球産生の低下， 2 . 赤血球寿命の短縮， 3 . 出血等 ${ }^{1}$ である。督性貧血の 発症機序は多様性であるが, 1 の赤血球産生の低下によ るところが多い，腎に肪ける erythropoietin (EPO) の

若杉 和倫 東京医科大学八王子医療センタ一免疫血液内科

干193八王子市舘町 1163 (0426-65-5611)
産生低下と尿毒症物筫による造血機能に対する抑制作 用，および鉄や葉酸等の造血物質の欠之による赤血球産 生能の低下が主たる要因である。また，血液透析 (HD) 療法中の患者では，機械的操作も加わって若干の赤血球 寿俞の短縮，および失血も関わっていると考えられてい る。

腎性賞血の血中 $\mathrm{EPO}$ 濃度は一般に低いといわれてい 
表 1 各種疾患に㧍ける末梢血と EPO 值

\begin{tabular}{cccrccc}
\hline Disease & $\begin{array}{c}\mathrm{WBC} \\
\left(/ \mathrm{mm}^{3}\right)\end{array}$ & $\begin{array}{c}\mathrm{RBC} \\
\left(10^{4} / \mathrm{mm}^{3}\right)\end{array}$ & $\begin{array}{c}\mathrm{Hb} \\
(\mathrm{g} / \mathrm{d} l)\end{array}$ & $\begin{array}{c}\mathrm{Ht} \\
(\%)\end{array}$ & $\begin{array}{c}\mathrm{Plt} \\
\left(10^{4} / \mathrm{mm}^{3}\right)\end{array}$ & $\begin{array}{c}\mathrm{EPO} \\
(\mathrm{mU} / \mathrm{m} l)\end{array}$ \\
\hline Normal mean & 5,807 & 451 & 14.0 & 43 & 24.1 & 14.9 \\
$(\mathrm{n}=73) \mathrm{SD}$ & 1,588 & 44 & 1.3 & 4 & 4.9 & 4.6 \\
$\mathrm{HD} \quad$ mean & 5,503 & 265 & 7.8 & 25 & 18.9 & 11.0 \\
$(\mathrm{n}=98)$ SD & 1,733 & 49 & 1.3 & 4 & 5.3 & 5.3 \\
IDA mean & 6,363 & 421 & 10.0 & 33 & 27.7 & 37.4 \\
$(\mathrm{n}=41) \mathrm{SD}$ & 2,616 & 33 & 1.2 & 2 & 10.2 & 118.5 \\
\hline
\end{tabular}

Normal : 健常人, HD : 血液透析, IDA : 鉄欠乏性貧血, $\mathrm{n}$ : 検体数, WBC : 白血球, $\mathrm{RBC}$ : 赤血球, $\mathrm{Hb}$ : 血色素, $\mathrm{Ht}$ ：ヘマトクリット, Plt：血小板, $\mathrm{EPO}$ ：エリスロポ エチンにて, mean士SD を表示する.

る2).しかしながら, どの程度低いのかという点について は報告されていないようである。

\section{対象および方法}

鉄欠乏性貧血（IDA）41名を対照，として健診時の諸 検查が正常範囲内で，かつ潜在性の鉄欠乏性貧血のない 健常人 73 名, 次に腎不全で HD療法中の患者 100 名を IDA 患者を対照として検討した。なお，検体は全て採血 後血清に分離して測定まで $-20^{\circ} \mathrm{C}$ に保存した。

$\mathrm{EPO}$ 測定は雪印乳業生物科学研究所上田正次博士に

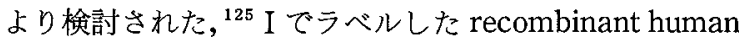
EPO (50 units/mg 蛋白) を用いて, radioimmunoassay (RIA) 法で測定した ${ }^{3)}$. EPO 測定に供した $\mathrm{EPO}$ その ものは166個のアミノ酸より構成され，分子量 34,000 dalton の糖蛋白で糖鎖を $30 \%$ 含有している.

\section{結果}

1. 対象症例の末梢血と EPO 值（表 1)

健常人73名 (検体) の赤血球数㹥 $451 \pm 44$ (mean $\pm \mathrm{SD}$ ) $\times 10^{4} / \mathrm{mm}^{3}$, 血色素量 $(\mathrm{Hb}) 14.0 \pm 1.3 \mathrm{~g} / \mathrm{d} l$, ヘマトク リット $(\mathrm{Ht}) 43 \pm 4 \%$, 血小板数 $24.1 \pm 4.9 \times 10^{4} / \mathrm{mm}^{3}, \mathrm{HD}$ 療法患者 98 名(検体) では, 赤血球数 $265 \pm 49 \times 10^{4} / \mathrm{mm}^{3}$, $\mathrm{Hb} 7.8 \pm 1.3 \mathrm{~g} / \mathrm{d} l, \mathrm{Ht} 25 \pm 4 \%$, 血小板数 $18.9 \pm 5.3 \times 10^{4} /$ $\mathrm{mm}^{3}$, IDA 患者は 41 名（検体）で, 赤血球数 $421 \pm 33 \times$ $10^{4} / \mathrm{mm}^{3}, \mathrm{Hb} 10.0 \pm 1.2 \mathrm{~g} / \mathrm{d} l, \mathrm{Ht} 33 \pm 2 \%$, 血小板数 27.7 $\pm 10.2 \times 10^{4} / \mathrm{mm}^{3}$ であった。

\section{2. 各疾患における EPO 值（図 1)}

健常人 73 検体では $14.9 \pm 4.6 \mathrm{mU} / \mathrm{m} l$ (mean $\pm \mathrm{SD}$ ) で, IDA 41 検体では $37.4 \pm 118.5 \mathrm{mU} / \mathrm{m} l$ と比較的広い 分布を示した。また，HD 100 検体では 2 例を除く 98 検 体で $11.0 \pm 5.3 \mathrm{mU} / \mathrm{m} l$ であった。

3 . 各疾患の $\mathrm{Hb}$ 值と $\mathrm{EPO}$ 值の関係（図 2)

各疾患の $\mathrm{Hb}$ 值と $\mathrm{EPO}$ 值の関係は HD 患者では EPO 值， $\mathrm{Hb}$ 值ともに低い領域に集団として分布する傾向を 示し, 健常人は $\mathrm{EPO}$ 值は低く, $\mathrm{Hb}$ 值は正常の領域に 分布した。

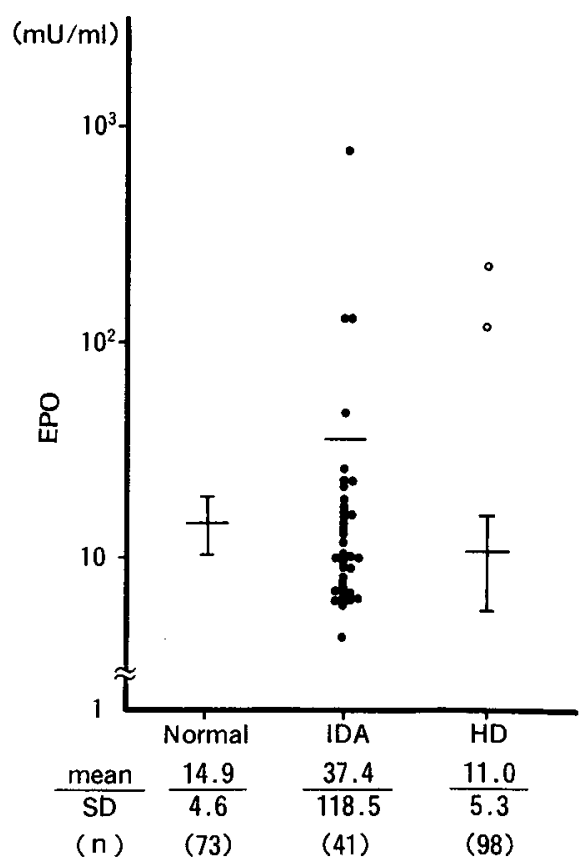

図 1 各疾患に打ける EPO 值. Normal：健常 人, IDA：鉄欠乏性貧血, HD：血液透析, EPO：エリスロポエチン，(n) は検体数. $\mathrm{HD}$ の○は多囊胞腎症にて平均から除外し た.よって, HD 98 例の平均土 $\mathrm{SD}$ と多囊 胞腎 2 例を図示した。

4. IDA 41 名と HD 98 名に扝ける $\mathrm{Hb}$ 值と $\mathrm{EPO}$ 值 の関係 (図 3 )

IDA 41 名における $\mathrm{Hb}$ 值と EPO 值の相関係数は $\mathrm{r}=-0.80$ となり, $\mathrm{y}=7,726 \mathrm{e}^{-0.63 \mathrm{x}}$ という逆相関が成り 立った。同様に HD 98 名では $\mathrm{r}=-0.16, \mathrm{y}=14.4 \mathrm{e}^{-0.044 \mathrm{x}}$ となった。

5. IDA 41 名と HD 98 名の $\mathrm{Ht}$ 值と $\mathrm{EPO}$ 值の関係 (図 4)

$\mathrm{Ht}$ 值と $\mathrm{EPO}$ 值は IDA 41 名では $\mathrm{r}=-0.48, \mathrm{y}=7,052$ 


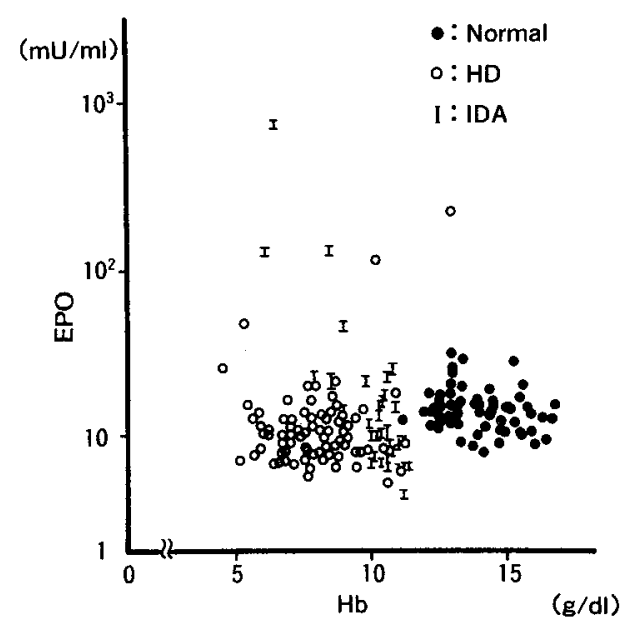

図 2 各疾患に扔ける $\mathrm{Hb}$ 值と $\mathrm{EPO}$ 值. $\mathrm{Hb}$ : 血 色素, EPO：エリスロポエチン, Normal : 健常人 73 例, HD：血液透析 100 例, IDA：鉄欠乏性貧血 41 例

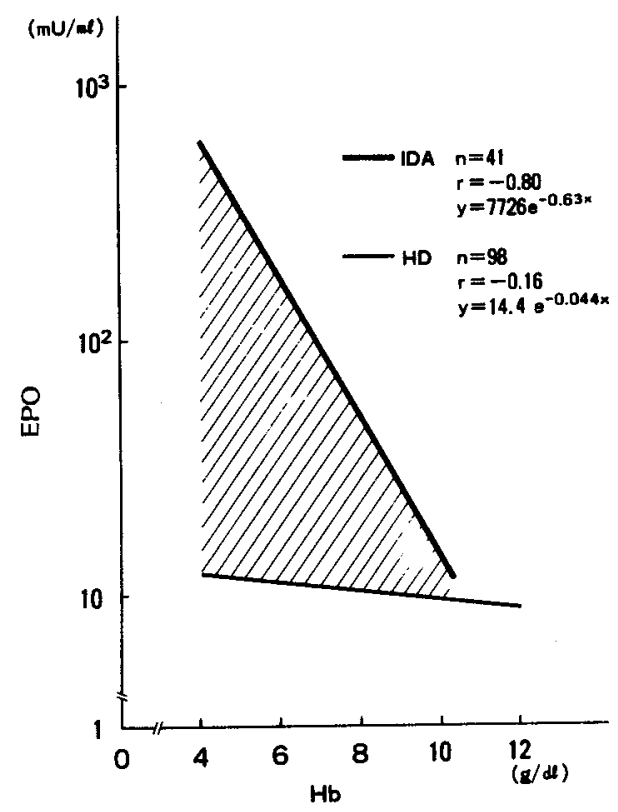

図 3 IDA患者と HD患者における $\mathrm{Hb}$ 值と $\mathrm{EPO}$ 值の関係. IDA：鉄欠之性貧血, HD：血液 透析, $\mathrm{Hb}$ : 血色素, EPO : エリスロポエチ ン

$\mathrm{e}^{-0.19 \mathrm{x}}, \mathrm{HD} 98$ 名では $\mathrm{r}=-0.11, \mathrm{y}=12.8 \mathrm{e}^{-0.0092 \mathrm{x}}, \mathrm{Hb}$ 值 ほど逆相関は良好ではないが, $\mathrm{Hb}$ 值と EPO 值の関係 同様に Ht 值と EPO 值の関係は図 4 に示した斜線部分 が得られた。

6. HD 98症例における $\mathrm{Hb}$ 值と $\mathrm{Ht}$ 值の関係(図 5 ) 一般に HD 療法をする診療の場では実際上, $\mathrm{Hb}$ 值よ

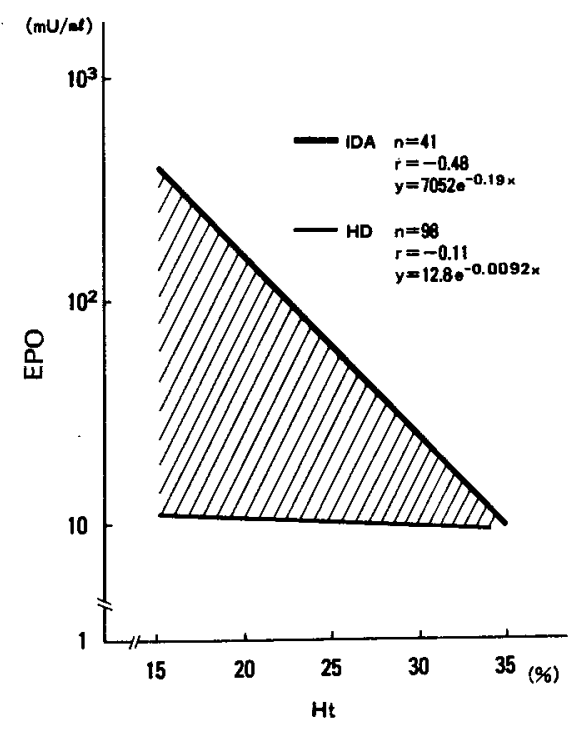

図 4 IDA 患者と HD 患者にお打る $\mathrm{Ht}$ 值とEPO 值の関係. IDA：鉄欠乏性貧血, HD：血液 透析, $\mathrm{Ht}$ ：ヘマトクリット, EPO：エリス ロポエチン

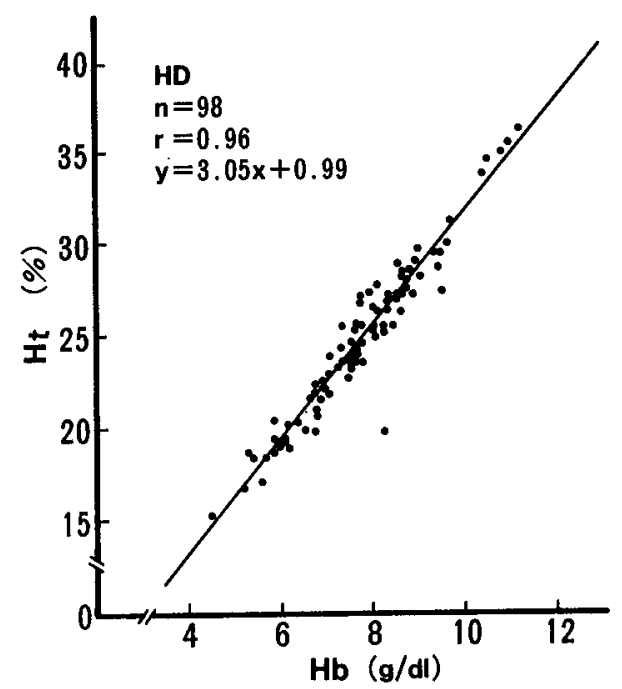

図 $5 \mathrm{HD} 98$ 例に括ける $\mathrm{Hb}$ 值と $\mathrm{Ht}$ 值の関係. $\mathrm{HD}$ : 血液透析, $\mathrm{Hb}$ ：血色素, Ht：ヘマト クリット

り $\mathrm{Ht}$ 值を用いることが多い. そこで, 今回の HD 症例 の $\mathrm{Hb}$ 值と $\mathrm{Ht}$ 值の相関係数を計算した. 図 5 に示すご とく, 今回の 98 症例では $\mathrm{r}=0.96, \mathrm{y}=3.05 \mathrm{x}+0.99$ で あった。これらから得られる $\mathrm{Hb}$ 值と $\mathrm{Ht}$ 值の関係では 診療の場における程度の問題差は生じないと考えた。

7. IDA 患者の回帰曲線から得られる EPO 推定値と HD 患者における EPO 実測值（表 2 ） 
表 2 IDA 患者の回帰曲線から得られる EPO 推定値と HD 患者の EPO 実測值

\begin{tabular}{|c|c|c|c|c|}
\hline$\underset{(\mathrm{g} / \mathrm{d} l)}{\mathrm{Hb}}$ & $\begin{array}{c}\mathrm{HD} \text { の } \mathrm{EPO} \text { 実測値 }{ }^{*} \\
(\mathrm{mU} / \mathrm{m} l)\end{array}$ & $\begin{array}{l}\text { IDA の回㷌曲線から得 } \\
\text { られた } \mathrm{EPO} \text { 推定值 } \\
(\mathrm{mU} / \mathrm{m} l)\end{array}$ & $\begin{array}{l}\mathrm{HD} \text { と IDA の } \\
\mathrm{EPO} \text { 解離 } \\
\quad(\mathrm{mU} / \mathrm{m} l) \text { 值 }\end{array}$ & $\begin{array}{c}\mathrm{HD} の \mathrm{Ht}-\mathrm{Hb} \\
\text { 回帰直線から } \\
\text { 得られた Ht 值 } \\
(\%)\end{array}$ \\
\hline 5.4 & 15.7 & 257.6 & 241.9 & 17.5 \\
\hline 5.9 & $11.3 \pm 2.4$ & 188.0 & 176.7 & 19.0 \\
\hline 6.2 & $10.5 \pm 0.3$ & 155.6 & 145.1 & 19.9 \\
\hline 6.8 & $8.6 \pm 2.2$ & 106.7 & 98.0 & 21.7 \\
\hline 7.4 & $10.5 \pm 0.6$ & 73.1 & 62.6 & 23.6 \\
\hline 7.7 & $11.3 \pm 5.1$ & 60.5 & 49.2 & 24.5 \\
\hline 8.3 & $10.2 \pm 2.5$ & 44.2 & 34.0 & 26.0 \\
\hline 8.7 & $12.7 \pm 6.1$ & 32.2 & 19.5 & 27.5 \\
\hline 9.1 & $10.7 \pm 0.9$ & 25.1 & 14.5 & 28.7 \\
\hline 9.5 & $7.2 \pm 0.8$ & 19.5 & 12.3 & 30.0 \\
\hline
\end{tabular}

* mean $\pm \mathrm{SD}, \mathrm{HD}$ : 血液透析, IDA : 鉄欠乏性貧血, $\mathrm{Hb}$ : 血色素, $\mathrm{Ht}$ ：ヘマトクリット, $\mathrm{EPO}$ :

エリスロポエチン

$\mathrm{Hb}$ 值 $5.4 \mathrm{~g} / \mathrm{d} l$ より $9.5 \mathrm{~g} / \mathrm{d} l$ までの $\mathrm{HD}$ 患者の $\mathrm{EPO}$ 実測值は $15.7 \mathrm{mU} / \mathrm{m} l$ から $7.2 \pm 0.8 \mathrm{mU} / \mathrm{m} l$ であり, IDA 患者の回帰曲線から得られた $\mathrm{EPO}$ 推定值は $257.6 \mathrm{mU} /$ $\mathrm{m} l$ から $19.5 \mathrm{mU} / \mathrm{m} l$ となり, $\mathrm{HD}$ 患者と IDA 患者間の $\mathrm{EPO}$ 解離值は $241.9 \sim 12.3 \mathrm{mU} / \mathrm{m} l$ となった。 そして, $\mathrm{HD}$ 療法中よく用いられる $\mathrm{Ht}$ 值を併記すると 17.5 $30.0 \%$ となった.

\section{考案}

Erythropoietin は腎の近位尿細管細胞より産生され， 糖鎖を除いた分子量は 18,399 dalton で，Jacobs ら ${ }^{4)}$ Lin ら ${ }^{5}$ によって塩基配列と全アミノ酸配列が報告され ている．その作用は赤血球系前駆細胞に働き，分化増殖 を促進させ，赤血球量を恒常的に保つ6). EPO の 80 90 \%は腎で，10〜20\%は主として肝で産生されている7 と 考光られている。

一般に鉄欠乏性貧血患者の $\mathrm{EPO}$ 値は $\mathrm{Hb}$ 濃度に逆比 例して高値であるとされている. Bear ら ${ }^{8)}$ は simple IDA 18 例の平均 $\mathrm{EPO}$ 濃度は $\mathrm{Hb} 9.1 \pm 0.2 \mathrm{~g} / \mathrm{d} l($ mean $\pm \mathrm{SE})$ で $138.0 \pm 1.3 \mathrm{mU} / \mathrm{m} l$ であったとしている．著者らの IDA 症例では $\mathrm{Hb} 10.0 \pm 1.2 \mathrm{~g} / \mathrm{d} l$ (mean $\pm \mathrm{SD})$ で $37.4 \pm$ $118.5 \mathrm{mU} / \mathrm{m} l$ であり, IDA 症例の $\mathrm{Hb}, \mathrm{EPO}$ 濃度による 回帰曲線から求めると我々の EPO 值と Bear $ら^{8)}$ のそれ は若干の差がある。

IDA 患者の $\mathrm{Hb}$ 濃度より $\mathrm{HD}$ 患者の $\mathrm{EPO}$ 濃度を推定 する報告はみられていない. 血中 $\mathrm{EPO}$ 量の $80 \sim 90 \%$ は 腎由来の EPO である点を踏まえて，骨䯣造血に障害の ない鉄欠泛性貧血を対照として Hb 濃度と必要 EPO の 濃度を測定した。そその結果, $\mathrm{Hb}$ 濃度が低くなればなるほ どこの両疾患の $\mathrm{EPO}$ 濃度差は広がる。しかし, 腎不全 である $\mathrm{HD}$ 症例といえども, ごく僅かに $\mathrm{EPO}$ 濃度は $\mathrm{Hb}$ 濃度が低下することによって上昇することが判明した。
実際上，日常的には慢性透析療法患者の貧血管理には $\mathrm{Ht}$ 值を代用する。そこで今度 $\mathrm{HD}$ 症例に扔いて, $\mathrm{Hb}$ 濃 度と $\mathrm{Ht}$ 值の関係をみると, $\mathrm{r}=0.96$ で $\mathrm{y}=3.05 \mathrm{x}+0.99$ という結果を得た。また，用いたこれらの試料は透析直 前に採血したので,やや $\mathrm{Ht}$ 值が患者の水分増量によっ て低下していると思われる。しかし, $\mathrm{r}=0.96$ の相関を得 た.

表 2 に HD 患者と IDA 患者の血中 EPO 值を計算し た. 今後 $\mathrm{EPO}$ 治療による $\mathrm{HD}$ 患者の貧血に対して $\mathrm{EPO}$ 投与量の指標に今回の IDA 患者の $\mathrm{Hb}$ 濃度よりみた $\mathrm{HD}$ 患者の $\mathrm{EPO}$ 推定值の結果は十分に参考になるもの と思われる．しかし，IDA 患者の貧血を改善するのにこ れだけの量の血中 EPO 濃度が必要だとは考えられな い. $\mathrm{EPO}$ 濃度にもその活性を示すだけの閾值 (抑制值と 活性值）が存在すると考えられる。

\section{結語}

慢性血液透析療法患者, 鉄欠乏性貧血患者, および健 常人等の血中 EPO 濃度を RIA 法で測定した。 その結 果, 1 . HD 患者 100 名 (うち 2 名は多囊胞腎にて除外) の $\mathrm{EPO}$ 濃度は $11.0 \pm 5.3 \mathrm{mU} / \mathrm{m} l, 41$ 名の IDA 患者では $37.4 \pm 118.5 \mathrm{mU} / \mathrm{m} l, 73$ 名の健常人では $14.9 \pm 4.6 \mathrm{mU} /$ $\mathrm{m} l$ であった. 2 . 血色素量と EPO 濃度より得られる関 係は IDA 患者では $\mathrm{r}=-0.80, \mathrm{y}=7,726 \mathrm{e}^{-0.63 \mathrm{x}}$ であり， $\mathrm{HD}$ 患者では $\mathrm{r}=-0.16, \mathrm{y}=14.4 \mathrm{e}^{-0.044 \mathrm{x}}$ で表現され，こ れらから得られる両疾患群の解離は $\mathrm{Hb}$ 濃度が低下寸る ほど広くなるという結果を得た。 3 。よって, $\mathrm{Hb}$ 濃度よ りみる HD 患者の血中 EPO 濃度は IDA 患者の $\mathrm{EPO}$ 濃 度に比較すると著明に低い，今後これらの結果は $\mathrm{EPO}$ による HD 患者の貧血治療に役立ち得るものと考元る.

本論文の主旨は第 33 回日本透析療法学会総会にて発表し 
た.

な抢, RIA 法による $\mathrm{EPO}$ 測定の指導わよび多数検体を測 定していただいた雪印乳業生物科学研究所上田正次博士记謝 意を表します。

\section{文献}

1）森下玲児：筫血の病態生理 - 診断と治療. 日本医事 新報 $3350: 3-7,1988$

2) McGonigle RJS, Wallin JD, Shadduck RK, Fisher $\mathrm{JW}$ : Erythropoietin deficiency and inhibition of erythropoiesis in renal insufficiency. Kidney Int $25: 437-444,1984$

3) Mizoguchi H, Ohta K, Suzuki T, Murakami A, Ueda M, Sasaki R, Chiba H : Basic conditions for radioimmunoassay of erythropoietin, and plasma levels of erythropoietin in normal subjects and anemic patients. Acta Haematol JPN $50: 15-24$, 1987

4) Jacobs K, Shoemaker C, Rudersdorf R, Neill SD, Kaufman RJ, Mufson A, Seehra J, Jones SS, Hewick R, Fritsch EF, Kawakita M, Shimizu T,
Miyake $\mathrm{T}$ : Isolation and characterization of genomic and cDNA clones of human erythropoietin. Nature $313: 806-810,1985$

5) Lin FK, Suggs $\mathrm{S}$, Lin CH, Browne JK, Smalling R, Egrie JC, Chen KK, Fox GM, Martin F, Stabinsky Z, Badrawi SM, Lai P-H, Goldwasser E : Cloning and expression of the human erythropoietin gene. Proc Natl Acad Sci USA 82 : 7580-7584, 1985

6) Taniguchi $Y$, Sakoda H, Yoshida Y, Uchino H, Ito $\mathrm{K}$ : Quantification of hemoglobin content in colonies derived from human early erythroid progenitor cells (BFU-E). Acta Haematol JPN $49: 1127-1139,1986$

7) Fried $\mathrm{W}:$ Factors that affect the rate of Erythropoietin production by extrarenal sites. Ann NY Acad Sci $554: 1-8,1989$

8) Baer AN, Dessypris EN, Goldwasser E, Krantz $\mathrm{SB}$ : Blunted erythropoietin response to anaemia in rheumatoid arthritis. Br J Haematol $66: 559$ $-564,1987$ 